\title{
Antihypertensive, Antidiabetic, Antioxidant and Cytotoxic Activities of Indonesian Traditional Medicine
}

\author{
Aprilita Rina Yanti Eff' ${ }^{1 *}$, Hermanus Ehe Hurit ${ }^{1}$, Sri Teguh Rahayu' ${ }^{1}$ Muhammad Unggul Januarko ${ }^{2}$, Putu Gita \\ Maya WM'2
}

\begin{abstract}
Aprilita Rina Yanti Eff ${ }^{1, *}$,
Hermanus Ehe Hurit ${ }^{1}$, Sri Teguh

Rahayu', Muhammad Unggul

Januarko², Putu Gita Maya WM²
\end{abstract}

'Department of Pharmacy Faculty of Health Science, Esa Unggul University, Jakarta, 1150 INDONESIA.

${ }^{2}$ Department of Management Faculty

Economics and Bussiness, Esa Unggul

University Jakarta, 1150, INDONESIA.

\section{Correspondence}

\section{Aprilita Rina Yanti Eff}

Department of Pharmacy Faculty of Health Science, Esa Unggul University, Jakarta, 1150, INDONESIA

E-mail: aprilita.rinayanti@esaunggul.ac.id History

- Submission Date:16-07-2020;

- Review completed: 11-08-2020;

- Accepted Date: 19-08-2020.

DOI : 10.5530/pj.2020.12.222

Article Available online http://www.phcogj.com/v12/i6s

\section{Copyright}

(C) 2020 Phcogi.Com. This is an openaccess article distributed under the terms of the Creative Commons Attribution 4.0 International license.

\begin{abstract}
Background: Indonesian people have long used herbal medicine (jamu) to overcome various diseases, including hypertension and diabetes mellitus. Hypertension and diabetes mellitus are two diseases that are directly related and require proper and thorough management. Objectives: The present study investigated the antihypertensive, antidiabetic, and cytotoxic activities ethanol extracts of Indonesian traditional medicine (jamu). Material and Methods: Jamu was extracted by maceration using ethanol. Antihypertensive and antidiabetic activity investigated by measurement of ACE inhibitor, an alpha-glucosidase inhibitor, and antioxidant activity at a concentration ranging from $125-1000 \mu \mathrm{g} / \mathrm{mL}$, respectively, by in vitro method. Cytotoxic evaluation of the extract was carried out using Brine Shrimp Lethality Test (BSLT). Results: measurements of ACE inhibitors, alpha-glucosidase inhibitor and antioxidant activity showed that herbal extracts had ACE inhibitors, alpha-glucosidase inhibitors, and antioxidant activity with IC50 values of $292.15 \mu \mathrm{g} / \mathrm{mL}, 36.13 \mu \mathrm{g} / \mathrm{mL}$, and $24.43 \mu \mathrm{g} / \mathrm{mL}$ respectively. Ethanol extract of herbal medicine (jamu) exerts a cytotoxic effect on larvae of shrimp Artemia salina with an IC50 value of $215.04 \mathrm{\mu g} / \mathrm{mL}$. Conclusion: Jamu extract has antihypertensive and antidiabetic activity in vitro and cytotoxic effects
\end{abstract}

Key words: Jamu, ACE inhibitors, Antioxidant, Alpha-glucosidase inhibitors, Cytotoxic.

\section{INTRODUCTION}

Herbal medicines are types of alternative medicine already used by Indonesian people from generation to generation. Traditional medicine represents an essential potential in the development of traditional medicines derived from plants. The use of traditional medicine is preferred because of the assumption that traditional medicine's side effects are relatively slighter when used correctly. Traditional medicine has a complementary or synergistic effect because traditional medicinal herbs generally consist of several types of medicinal plants that support each other to achieve the effectiveness of treatment. ${ }^{1}$

Hypertension and diabetes mellitus are two diseases that are directly related and require proper and thorough management. Hypertension does not merely cause heart attack, heart failure, and stroke, but in many cases, it often causes diabetes mellitus. To avoid being exposed to diabetes, hypertension sufferers were asked to maintain his blood pressure by keeping up body weight, levels of glucose, triglycerides, HDL, and LDL. The number of sufferer's diabetes in Indonesia is increasing every year as increasingly sufferers hypertension and heart disease. ${ }^{2}$ Several studies have found an association between increased high blood pressure in patients with diabetes mellitus (DM). People who suffer from DM, primarily type 2 have a risk of 2 to 4 times more susceptible to death due to cardiovascular abnormalities than those who do not suffer from DM.
Conversely, the incidence of hypertension occurs two times more susceptible in patients with DM compared to un DM in the same age group. In most diabetic populations, $80 \%$ of diabetic patient's complication with hypertension, and vice versa, $70 \%$ of hypertensive patients may experience impaired glucose tolerance or develop type 2 diabetes. Targets for reducing blood pressure in hypertensive patients with diabetes are $<130$ for systolic blood pressure and $<90$ for diastolic blood pressure. Diabetes patients who are accompanied by hypertension will further increase the risk of coronary heart disease, stroke, nephropathy, and retinopathy. DM accompanied by hypertension increases by $75 \%$ morbidity and mortality in people who have previous risk factors. ${ }^{2,3} \mathrm{DM}$ causes metabolic changes, including hyperglycemia, excessive expenditure of free fatty acids, and insulin resistance, which causes abnormalities of endothelial cell function because of a decrease in nitric oxide (NO). Impaired glucose tolerance in DM patients causes an increase in free fatty acids which causes endothelial damage and the incidence of hypertension. ${ }^{4}$

Management of hypertension can be done by non-pharmacologically and pharmacologically. Nonpharmacological therapy includes a low salt diet, regular exercise, limiting fat, sugar, and alcohol intake. Pharmacological therapy is done by giving antihypertensive drugs. The inappropriate selection of antihypertensive drugs in diabetic patients can worsen glycemic control. Some antihypertensive drugs can affect blood glucose level parameters, insulin sensitivity, and $\mathrm{HbAlc}$. 
Beta-blockers and thiazide diuretics can increase blood glucose levels and cause hyperglycemic coma at high doses. ACE inhibitors (ACEI) and Angiotensin Receptor Blocker (ARB) in hypertensive patients with diabetes complications possess a potential effect in lowering blood pressure, and is beneficial in preventing microalbuminuria, worsening kidney function, and other microvascular complications. ${ }^{5}$ ACE inhibitors work by inhibiting the effects of angiotensin II, which are as vasoconstrictors. ACE inhibitors obtain the drug of choice in hypertension with diabetes because, in addition to the treatment of hypertension, it equally affects renal hemodynamics which can reduce glomerular hydraulic pressure. ACE inhibitors can lower glomerular hypertension and proteinuria by modifying pressure capillaries and glomerular permeability. ACE inhibitors beneficial for reducing protein excretion urine in diabetic or non-diabetic kidney disease. In patients with diabetes and hypertension with albuminuria, ACE inhibitors represent the first choice. ${ }^{3}$

The use of traditional medicines has been thoroughly developed and is counted as an integral component in essential health services. Traditional medicine, as part of the treatment of hypertension, has increased in the last decade. The contributing factor is mainly the price of traditional medicines, which are considered cheaper with fewer side effects. Some medicinal plants in Indonesia possess antihypertensive activities, including Persea Americana, Phalleria macrocarpa, Oxalis corniculata, Catharanthus roseus, Scurulla artopurpurea, Swietenia mahogany, Gynura procumbens, Melia azedarach L, Morindae citrofolia, Phyllanthus niruri, Centella asiatica, Zingiber officinale, Alyxia reinwardtii and Hibiscus rosasinensis. ${ }^{6}$ Several extracts and compounds derived from plants have been proven in vitro to have an ACE inhibitors effect. ACE inhibitors obtained from natural materials studied are peptides derived from animals, plants, and microorganisms. Milk, meat, and eggs are ACE inhibitors derived from animals. Casein, hydrolyzed protein from milk and ovokinin from eggs in vitro and invivo are reported to possess an effective and safe ACE inhibitor. ${ }^{7,8}$

Toxic activity assay is one of the prerequisites for a plant to be developed as a drug, especially as an anticancer. One method used to determine extracts or natural compounds' toxic activity is the Brine Shrimp Lethality Test. Some of this method's advantages are rapid (24 h), easy, inexpensive, does not need a particular specialization in its performance, and possesses a high level of confidence. The number of Artemia salina Leach larvae that die because of the influence of extracts or natural compound substances at a given concentration illustrates the toxicity of a material. Extracts or compounds of natural material known to possess toxic activity with an $\mathrm{LC}_{50}$ value $<1000 \mathrm{ppm}$ can be developed as anticancer drugs. ${ }^{9}$ This study aims to investigate the antihypertensive, antidiabetic and cytotoxic activities of Indonesian traditional medicine (jamu). The composition of plants in herbal medicine consists of Morindae citrofolia fructus, Phyllanthus niruri herba, Centella asiatica herba, Zingiber officinale rhizoma, and Alyxia reinwardtii cortex.

\section{MATERIAL AND METHODS}

Herbal medicine (Jamu) were obtained from herbal Market in Jakarta, Ethanol (Bratachem), Aquadest (Bratachem), Aquademineral (Bratachem), Ethyl Acetate (Merck), DMSO (Merck), Hippuric Acid (Sigma), Captopril (Sigma), HHL (Sigma), ACE from rabbit lung (Sigma), $\mathrm{NaOH}$ (Merck), Boric Acid (Sigma), DPPH (Merc), vitamin C (sigma). A-Glucosidase (Sigma), p-nitrophenyl- $\alpha$-D-glucopyranoside substrate (Sigma), dimethyl sulfoxide (DMSO) (Merck), Bovine Serum Albumin (BSA) (sigma), $\mathrm{Na}_{2} \mathrm{CO}_{3}$ (Merck), buffer phosphate $\mathrm{pH} 7$, acarbose (Sigma), Anemia salina Leach. (Brine eggs), NaCI (Merck).

\section{Extract preparation and standardization}

A total of 500 grams of herbal medicine powder was extracted by maceration using $70 \%$ ethanol and stirred for 3 hours. The maceration process is carried out for 24 hours. The filtrate is carefully separated from the residue using filter paper. The residue is macerated again, and the process is repeated until a clear filtrate is obtained. Filtrat maceration results are combined, and the solvent is evaporated using a rotary evaporator to obtain a thick extract. Standardization of non-specific parameters includes checking ash content, ash content, which is insoluble in acid, water content, levels of extracts that are soluble in water, compounds that are soluble in ethanol, and coliform contamination and mold/yeast rates utilizing the ALT method. Standardization of specific parameters involves organoleptic, extract chemical content, and identification of the infrared spectrum.

\section{In-vitro ACE inhibitor activity assay}

Measurement of in vitro ACE inhibitor activity is carried out using a spectrophotometer under aerobic conditions. A total of $50 \mu \mathrm{L}$ of the assay solution was put into a test tube, $50 \mu \mathrm{L}$ of HHL substrate was added and pre-incubated at $37^{\circ} \mathrm{C}$ for 10 minutes. After that, $100 \mu \mathrm{L}$ of ACE enzyme solution was added to the test tube and homogenized with a vortex. The mixture was incubated at $37^{\circ} \mathrm{C}$ for 90 minutes. To the solution, the mixture was included $250 \mu \mathrm{L}$ HCI $1 \mathrm{~N}$ to prevent the reaction. The formed hippuric acid was extracted using $1.5 \mathrm{~mL}$ ethyl acetate and centrifuged for 10 minutes. The ethyl acetate layer is taken gradually and evaporated at $100^{\circ} \mathrm{C}$ for 5 minutes. The formed precipitate was dissolved with $3 \mathrm{~mL}$ aquadest. The absorption of the solution is measured using a spectrophotometer at a wavelength of 246 $\mathrm{nm}$. A similar procedure was carried out with Captopril as a standard. Boric acid buffer solution as a blank and blank control. A solution has added the enzyme solution in a blank, whereas in control blank, not added enzyme solution. The results determining ACE inhibitor activity compared with a Captopril. ${ }^{8,10,11}$

\section{In-vitro antioxidant activity assay}

A total of $500 \mu \mathrm{L}$ extracts at concentrations of $125,250,500,750$, and $1000 \mathrm{ppm}$ added with $500 \mu \mathrm{L}$ DPPH $0.125 \mathrm{mM}$. The mixture is then vortexed and incubated for 30 minutes. The absorption of test solutions and blanks was measured at a wavelength of $517 \mathrm{~nm}$. The results of determining antioxidants compared with a vitamin C. ${ }^{12,13}$

\section{In vitro alpha-glucosidase inhibitor activity}

A total of $10 \mu \mathrm{L}$ of extract solution each at concentrations of 125,250 , 500,750 , and $1000 \mathrm{ppm}$ was added $50 \mu \mathrm{L}$ of phosphate buffer solution $\mathrm{pH} 7$, and $25 \mu \mathrm{L}$ p-nitrophenyl- $\alpha$-D-glucopyranoside $10 \mathrm{mM}$. Next to the solution was added $25 \mu \mathrm{L}$ of $0.04 \mathrm{U} / \mathrm{mL}$ enzyme solution and incubated at the time and temperature optimum. Then $100 \mu \mathrm{L} \mathrm{Na}_{2} \mathrm{CO}_{3}$ $200 \mathrm{mM}$ was added. The absorbance was measured with a microplate reader at a wavelength of $410 \mathrm{~nm}$. Percent inhibition is calculated using the formula: $A_{0}-A_{1}$

$$
A_{1}
$$

Where $A_{0}$ is the absorbance of the control, $A_{1}$ is the absorbance of the sample. $\mathrm{IC}_{50}$ is calculated using linear regression by plotting the concentration of percent inhibition. The results of determining alphaglucoside inhibitor activity compared with an Acarbose. ${ }^{14}$

\section{Brine shrimp lethality bioassay}

A total of $50 \mathrm{mg}$ of extract was added to $5 \mathrm{ml}$ of dimethyl sulfoxide (DMSO) until a $10 \mathrm{mg} / \mathrm{ml}$ stock solution was obtained. Concentration series of test samples were made at concentrations of $5,10,25,50$, and $100 \mathrm{ppm}$ by taking a specific volume of stock solution using a micropipette and place it in flacons. A. salina larvae eggs are hatched in a dark room in seawater media and aerated using aerators. The eggs will hatch about 24 hours into larvae. 48 -hour-old larvae can be used for toxicity testing. Sample testing is done by inserting each sample into the flacon, evaporating with aerated until the solvent is lost. Next, 
flacon filled with $1 \mathrm{~mL}$ of seawater, then vortexed for approximately to homogenize the sample. Ten tails of A. salina Leach. Age 48 hours a good (active move) randomly selected, put into flacons containing solvent-free samples using a dropper pipette then added seawater to 5 $\mathrm{mL}$. One drop of yeast suspension Saccharomyces cerevisiae $(3 \mathrm{mg} / 10$ $\mathrm{ml}$ of seawater) is added to it as A. salina Leach food. The flacons are placed under the lighting for 24 hours, and the number of A. salina Leach larvae dead is counted. ${ }^{14,15}$ Percent mortality of larvae is calculated following the formula ${ }^{15}$ :

$\%$ Death $=$ number of A. salina larvae dead x 100\%

number of test larvae

\section{RESULTS}

Result of standardization both specific and nonspecific parameter presented in Table 1 and Table 2.

Data ACE inhibitory, $\alpha$-glucosidase inhibitory, and antioxidant activity are presented in Table 3.

Results of Brine shrimp lethality bioassay presented in Table 4 .

\section{DISCUSSION}

Based on the Regulation of Indonesia National Agency of Drug and Food Control No. 12/2014 concerning quality requirements for traditional medicines, it is seen that the extract of herbal medicine meets non-specific or specific parameters. Standardization of pharmaceutical products is carried out so that an extract meets the established chemical, biological, and pharmaceutical standards requirements. Standardization will guarantee that the extract or extract product has a constant parameter value. Standardization is the process of determining properties based on specific parameters to achieve the same degree of quality. Standardization of extracts is done by using two parameters, namely specific parameters, and non-specific parameters. Water content is one of the essential characteristics of the extract.
Determination of the water content in the extract aims to provide a minimum limit or range of the amount of water content in the extract. Extracts that have high water content are natural to grow with mold and yeast to reduce the biological activity of the extract in the storage period. Water content depends on the plant's drying time, the drier, the smaller the water content. Based on the Regulation of Indonesia National Agency of Drug and Food Control No. 12/2014, it is seen that the extracts of herbs meet the water content requirements of $<10 \%(6.82 \pm 0.2)$. Ash content is a mixture of inorganic components or minerals found in an ingredient. Organic materials in the combustion process will burn but not the inorganic components. The ash content was determined by inserting the extract into the furnace at $450^{\circ} \mathrm{C}$ until ash was formed. Total ash content can also be used to know the internal and external mineral content from the initial process to the end of extracting. The extract ash content of $4.63 \pm 0.08$ and an acid insoluble ash content of $0.28 \pm 0.02$. This value is the following required in Herbal Pharmacopoeia, which is less than $7.8 \%$. Small ash content values mark if the remaining material is small. The remaining material includes physiological ash derived from the plant tissue itself and nonphysiological ash, a residue from foreign material attached to the plant's surface, such as sand and soil. The smaller the value of ash content can be, the smaller the impurity in the resulting fraction.

Water-soluble and ethanol extract levels are indicators of active compounds that can be detected, both by water and ethanol solvents. The level of active compound in a plant is influenced by plant age, harvest time and climate, and place of growth. The test results showed that herbal medicine's extracted content in aqueous solution was 28.38 $\pm 0.68 \%$, and ethanol soluble was $57.62 \pm 0.55 \%$. These results are quite indicative that the active compound in the herbal extract is quickly scattered into water and ethanol. The low water content will prevent the growth of microorganisms and mold (fungus). Aspergillus flavus will produce aflatoxin, which is very toxic and can cause liver cancer. According to traditional medicine requirements, it is stated that the rate of yeast or mold does not exceed $104 \mathrm{CFU/gr.} \mathrm{The} \mathrm{extract} \mathrm{must} \mathrm{be}$

Table 1: The specific parameters.

\begin{tabular}{ccc} 
& Parameter & \\
\hline $\begin{array}{c}\text { Organoleptic } \\
\text { (colour and texture) }\end{array}$ & Chemical content & identification of infrared spectrum \\
yellowish-brown and paste & Flavonoid, tannin, saponin, steroid & $\begin{array}{l}\text { C=O; -OH; C=C; C-O' C-H } \\
\text { (aromatic); C-H (aliphatic) }\end{array}$ \\
\hline
\end{tabular}

Table 2: The nonspecific parameters.

\begin{tabular}{ccccccc}
\hline & \multicolumn{5}{c}{ Parameter } \\
water content $(\mathrm{v} / \mathrm{w})$ & ash content $(\mathrm{w} / \mathrm{w})$ & $\begin{array}{c}\text { Ash insoluble acid } \\
\text { content }\end{array}$ & $\begin{array}{c}\text { level of substances } \\
\text { dissolved in alcohol } \\
(\%)\end{array}$ & $\begin{array}{c}\text { Level of substances } \\
\text { dissolved water }(\%)\end{array}$ & $\begin{array}{c}\text { Coliform microbial } \\
\text { contamination } \\
\text { (colony/g) }\end{array}$ & $\begin{array}{c}\text { mold / yeast numbers } \\
\text { (colony/g) }\end{array}$ \\
$6.82 \pm 0.2$ & $4.63 \pm 0.08$ & $0.28 \pm 0.02$ & $57.62 \pm 0.55$ & $28.38 \pm 0.68$ & negative & negative
\end{tabular}

Table 3: ACE inhibitory, $\alpha$-glucosidase inhibitory and antioxidant activity $\left(\mathrm{IC}_{50}\right)$.

\begin{tabular}{cccc}
\hline \multirow{2}{*}{ Sample } & & $\mathrm{IC}_{50}(\mu \mathrm{g} / \mathrm{ml})$ & \\
& ACE inhibitor & a-glucosidase & antioxidant \\
\hline Extract & 292.15 & 36.13 & 24.43 \\
Standard & 0.64 & 0.268 & 5.13 \\
\hline
\end{tabular}

Table 4: Effect of ethanol extract jamu of various concentrations on mortality against Brine shrimp.

\begin{tabular}{ccccc}
\hline Concentration $(\mu \mathrm{g} / \mathrm{ml})$ & Log concentration $(\mu \mathrm{g} / \mathrm{ml})$ & $\%$ mortality & Probit value & $\mathrm{LC}_{50}(\mu \mathrm{g} / \mathrm{ml})$ \\
\hline 1000 & 3 & 80 & 5.8416 & 215.04 \\
500 & 2.6899 & 66.7 & 5.4316 & \\
100 & 2 & 36 & 4.6415 & \\
50 & 1.6990 & 20 & 4.1684 & \\
10 & 1 & 4.5 & 3.3046 & \\
\hline
\end{tabular}


uncontaminated with pathogenic microbes, and the aflatoxin content is no more than 30 parts per million (ppm). Examination results of mold/ yeast extract uncontaminated with mold/yeast. A natural medicinal product should not contain microorganism contamination, but this is difficult to avoid. The maximum limit of microorganism contamination required depends on the dosage form and is determined by the Total Plate and Yeast Fungi Numbers' determination. Natural medicinal products are unpermitted to contain pathogenic microorganisms like Pseudomonas aeruginosa, Staphylococcus aureus, and Clostridia sp. Shigella sp., and Salmonella sp. The permitted value or range is related to purity and contamination. The results showed that the extract was uncontaminated with microbial coliform.

Pathophysiology of Diabetes mellitus and hypertension occurs through several mechanisms such as improper activation of the angiotensin aldosterone (RAAS) system, secondary oxidative stress that causes over-production of reactive oxygen species (ROS), inflammation, vasoconstriction due to insulin, increased activation of the sympathetic nervous system and kidney abnormalities in secreting sodium. ${ }^{16}$ The key factors causing the coexistence of diabetes mellitus with hypertension are obesity and increased visceral adiposity. Mild chronic inflammation and oxidative stress in adipose tissue cause an increase in angiotensinogen and angiotensin II production, which results in the activation of RAAS tissue. Overexpression of angiotensinogen in adipose tissue causes an increase in blood pressure. ${ }^{17}$ Hypertension in diabetic patients can increase both microvascular and macrovascular complications. Proper management of hypertension is needed to minimize the occurrence of complications and inhibit disease progression. Barriers to the reninangiotensin aldosterone system by ACE inhibitors or angiotensin receptor blockers can increase glucose metabolism by preventing the formation of angiotensin II or preventing the activation of Angiotensin II receptors. ${ }^{18} \mathrm{ACE}$ inhibitors are antihypertensive drugs that have been used for the past several decades. Captopril, Lisinopril, Enalapril, and Rampiril are some examples of drugs that target ACE inhibitors. The use of these drugs in the long term can cause side effects like dizziness, coughing, and angioneurotic edema. ${ }^{19}$ Research to seek new drugs continues to be done, one of which represents the search for bioactive compounds from nature as a target. Some natural bioactive compounds that have been investigated to have ACE inhibitor activity are peptides, anthocyanins, flavonols, and triterpenes. ${ }^{7}$

Table 3 shows that the extract has an ACE inhibitor, a-glucosidase inhibitory, and antioxidant activity with an $\mathrm{IC}_{50}$ value of $292.15 \mu \mathrm{g} / \mathrm{ml}$, $36.13 \mu \mathrm{g} / \mathrm{ml}$, and $24.43 \mu \mathrm{g} / \mathrm{ml}$, respectively. Herbal extracts containing flavonoids, tannins, saponins, and steroids (Table 1). Secondary metabolites produced by plants are a group of natural compounds that are identified as potential ACE inhibitors. Some terpenoids and polyphenolic compounds, including flavonoids, hydrolyzable tannins, xanthones, procyanidin, caffeoylquinic acid derivatives, turned out to obtain an effective natural ACE inhibitor. Almost all studies show that plant extracts which are rich in phytochemicals are useful as ACE inhibitors. ${ }^{7}$

The development of insulin resistance, hypertension, and diabetes mellitus occurs due to oxidative stress. ROS can cause impaired endothelial function, tissue injury, reduction of bioavailable Nitrite oxide (NO), and impaired $\mathrm{NO}$-mediated vasodilatation.

The herbs used in this study consisted of plants, namely Morindae citrofolia Fructus, Phyllanthi niruri Herb, Centella asiatica Herb, Zingiberis officinale rhizome, Imperata radix, and Alyxiae cortex. These six plants contribute to their antihypertensive and antidiabetic activities.

People widely use Morinda citrifolia L as natural medicine. The content of flavonoids in this plant function as an antioxidant that can withstand the rate of absorption blood glucose from the digestive tract to the blood vessels so that able to withstand the rate of increase in blood glucose levels. Bioactive components such as flavonoids, triterpenoids, and saponins a significant amount has a hypoglycemic effect. ${ }^{20}$ Morinda citrifolia has antioxidant activity that can inhibit the rate of formation of Advanced Glycation End Products (AGEs) and dicarbonyl compounds. The binding of AGEs to the AGEs (RAGE) receptor triggers reactive oxygen species (ROS) and NF-B activation of target cells, endothelium, mesangial cells, and macrophages an increase in permeability vascular. ${ }^{21}$ A study conducted by Mutia et al., 2017 shows that ethanol extract of Morinda citrofolia has ACE inhibitor activity with a percent inhibition against ACE of $66.64+2.32 \%{ }^{22}$ Scopoletin phenolic compounds and routine have an antihypertensive effect through the ACE inhibitor mechanism and antioxidant activity. ${ }^{23}$

Phyllanthi niruri L has been empirically used in the management of diabetes and hypertension. Bioactive substances like glycosides, flavonoids, saponins, tannins, sterols, and carbohydrates are thought to be responsible for their actions. We already know certain flavonoids have hypoglycemic effects because they can regenerate pancreatic betacell regeneration. Studies in experimental animals have shown that sterol compounds can reduce blood sugar, whereas cardiac glycosides have cardio-protective and cardiotonic activity. A study conducted by Bharati et al., 2017 shows that ethanol extract of leaves and fruit of $P$. niruri decreases blood pressure in diabetic hypertensive animals. ${ }^{24}$ $P$ niruri fruit juice comprises ACE inhibitory compounds, and daily consumption of the juice is useful for prevention and healing against hypertension. ${ }^{25}$

Centella asiatica (L.) is a plant that has long been used in traditional medicine for various indications like skin disorders, vascular disorders, microangiopathy, and inflammation. This plant also has vigorous antioxidant activity with the chemical content of phenolic compounds, namely flavonoids (quercetin, kaempferol, catechin, routine, apigenin, and naringin), triterpenoids (asiaticoside, madecassoside, asiatic acid, madecassic acid), glycosides, flavonoids, alkaloids, steroids, volatile and fatty oils. C. asiatica extract can reduce blood pressure in rats that are made hypertensive with L-NAME. Quercetin may act in components sufficient for the antihypertensive effect of C. asiatica extract. ${ }^{26}$ Ethanolic extract of freeze-dried and juice C. asiatica has ACE inhibitor activity with $\mathrm{IC}_{50}$ of $1 \mathrm{mg}$ and $1.6 \mathrm{mg}$, respectively, advising possible usage as natural antihypertensive medicine. ${ }^{27} \mathrm{C}$ asiatica also has antidiabetic activity in Alloxan induced diabetic rats. C. asiatica could restore the damage of the pancreatic $\beta$-cells and improve insulin synthesis, thus reducing plasma glucose level. The two glycosides, brahmoside and brahminoside, which are essential components of $C$. asiatica, have been confirmed to exert sedative and hypoglycemic effects in rats. ${ }^{26}$

Ginger (Zingiber officinale Roscoe) is a tropical plant used as a spice and has a therapeutic effect on various diseases like anticancer, anticoagulant, and antiemetic hypolipidemic and antioxidant. The main bioactive compounds contained in ginger obtain gingerol, with other gingerol analogs like shogoals, paradol, and zingerone. Gingerol compounds have antioxidant activity in vitro by protecting HL-60 cells against oxidative stress. Ginger oil protects DNA from damage by $\mathrm{H} 2 \mathrm{O} 2$. Ginger oil can serve an oxygen radical scavenger and can be used as an antioxidant. ${ }^{28,29}$ The administration of $Z$. officinale juice at a dose of $4 \mathrm{ml} / \mathrm{kg}$ once daily decreases blood glucose levels and increases plasma insulin in mice induced by streptozotocin. Z. officinale juice also lowers cholesterol, triglycerides, and blood pressure. ${ }^{30}$

Imperata cylindrica contains potassium, flavonoids, graminone $\mathrm{B}$, and cylindrene, which is useful for treating various diseases, including hypertension. Infusion I cylindrica in 15 healthy volunteers reduced systole and diastolic blood pressure significantly lower $(\mathrm{p}<0.01)$ than before drinking infusion. The presence of flavonoids on I cylindrica exerts the effect of inhibiting the Angiotensin Converting Enzyme. 
Potassium obtains anti-renin and inhibits aldosterone secretion. Potassium can decrease membrane potential, causing relaxation of vascular smooth muscle. ${ }^{31}$ Ethanol extract of I cylindrica dose of 500 $\mathrm{mg} / \mathrm{kg}$ has an antidiabetic effect in alloxan-induced mice. ${ }^{32}$

Alyxia reinwardtii is a medicinal plant used to manage various diseases. The fruit can reduce fever, and the flower is effective in treating mental confusion and hallucinations, and the stem is used for heart failure and stomach discomfort due to gas distension. Chemical compounds in the cortex are iridoids, coumarin, and isolated lignans that have antioxidant activity. ${ }^{33}$

Our previous study showed that herbal extracts containing Phaleria macrocarpa, Gynura procumbens, Imperata cylindrica, Centella asiatica, and Syzygium polyanthum had ACE inhibitors activity with $\mathrm{IC}_{50}$ values of $18.37 \mathrm{ppm}^{34}$

Toxic activity assay is one of the prerequisites for a plant to be developed as a drug, especially as an anticancer. Brine shrimp lethality test (BSLT) is a simple, inexpensive, non-aseptic, and high potentiality cytotoxicity test for bioactive compounds and used as a preliminary test to determine the activity of a substance or a compounds contained in an-pure extract or plant isolate..$^{35}$ Acute toxicity can be measured as a concentration that can kill $50 \%$ of the tested animal population. $\mathrm{LC}_{50}$ lethal concentrations were assessed at $95 \%$ confidence intervals using probit analysis. Toxicity assays using Artemia Salina can be used in filtering out various chemical compounds that have bioactivity. ${ }^{15}$ Table 4 shows that the jamu extract possesses cytotoxic activity with an $\mathrm{LC}_{50}$ value of $215.04 \mu \mathrm{g} / \mathrm{ml}$. Larvae mortality was seen to be directly proportional to the extract concentration, starting from the lowest (10 $\mu \mathrm{g} / \mathrm{ml})$ to the highest $(100 \mu \mathrm{g} / \mathrm{ml})$. An extract is said to be toxic if it has an $\mathrm{LC}_{50}<1000 \mu \mathrm{g} / \mathrm{ml}$. If the BSLT test results indicate that a plant extract is toxic, it can be developed to isolate its bioactive compounds. ${ }^{36}$

\section{CONCLUSION}

Jamu extract has ACE inhibitors, alpha-glucosidase inhibitors, and antioxidant activity with $\mathrm{IC}_{50}$ values of $292.15 \mu \mathrm{g} / \mathrm{mL}, 36.13 \mu \mathrm{g} / \mathrm{mL}$, and $24.43 \mu \mathrm{g} / \mathrm{mL}$, respectively. Ethanol extract of jamu exerts a cytotoxic effect on larvae of shrimp Artemia salina with an $\mathrm{IC}_{50}$ value of 215.04 $\mu \mathrm{g} / \mathrm{mL}$.

\section{ACKNOWLEDGMENTS}

The authors express their gratitude to the Indonesia Ministry of Research, Technology and Higher Education for the funding of this research.

\section{CONFLICTS OF INTEREST}

No conflicts of interest to be declared by authors.

\section{REFERENCES}

1. Anonim. Indonesian Traditional Medicine National Strategy and Scope of Cooperation [Internet]. http://www.searo.who.int/entity/medicines/topics/ traditional_medicines_in_republic_of_indonesia.pdf. 2019 [cited 2019 Apr 15]. p. 23-36. Available from: http://www.searo.who.int/entity/medicines/topics/ traditional_medicines_in_republic_of_indonesia.pdf

2. Tsimihodimos V, Gonzalez-Villalpando C, Meigs JB, Ferrannini E. Hypertension and Diabetes Mellitus Coprediction and Time Trajectories. Hypertension. 2018;71(3):422-8

3. Lastra G, Syed S, Kurukulasuriya LR, Manric C, Sowers JR. Diabetes, Hypertension, and Cardiovascular Disease. Endocrinol Metab Clin North Am. 2014;43(1): 103-122.

4. De Boer IH, Bangalore S, Benetos A, Davis AM, Michos ED, Muntner P, et al. Diabetes and hypertension: A position statement by the American diabetes association. Diabetes Care. 2017;40(9):1273-84.

5. Standl E, Erbach M, Schnell O. What should be the antihypertensive drug of choice in diabetic patients and should we avoid drugs that increase glucose levels? Pro and Cons. Diabetes Metab Res Rev. 2012;28(SUPPL.2):60-6.
6. Rahmawati R, Bajorek B. The use of traditional medicines to lower blood pressure. Australas Med J. 2018;11(3):153-62.

7. Balasuriya BWN, Rupasinghe HPV. Plant flavonoids as Angiotensin Converting Enzyme inhibitors in regulation of hypertension. Funct Foods Heal Dis. 2011;5:172-88.

8. Rinayanti A, Radji M, Mun A, Suyatna FD. Screening Angiotensin Converting Enzyme (ACE ) Inhibitor Activity of Antihypertensive Medicinal Plants from Indonesia. Int J Pharm Teach Pract. 2013;4(1):527-32.

9. Libralato G, Prato E, Migliore L, Cicero AM, Manfra L. A review of toxicity testing protocols and endpoints with Artemia spp. Ecol Indic. 2016;69:35-49.

10. Effect of Pomegranate Juice on Angiotensin-II induced hypertension in diabetic Wistar rat. Phytother Res. 2010;24(Suppl 2):S196-203

11. Gao D, Chang T, Li H, Cao Y. Angiotensin I-converting enzyme inhibitor derived from cottonseed protein hydrolysate. African J Biotechnol. 2010;9(53):8977-82.

12. Kedare SB, Singh RP. Genesis and development of DPPH method of antioxidant assay. J Food Sci Technol. 2011;48(4):412-22.

13. Shekhar CT, Anju G. Antioxidant Activity by DPPH Radical Scavenging Method of Ageratum conyzoides Linn. Leaves. Am J Ethnomedicine. 2014;1(4):244-9.

14. Elya B, Basah K, Mun'im A, Yuliastuti W, Bangu A, Septiana KE. Screening of $\alpha$-Glucosidase Inhibitory Activity from.pdf. J Biomed Biotechnol. 2012;2012:1-7.

15. Naidu JR, Ismail R, Sasidharan S. Acute oral toxicity and brine shrimp lethality of methanol extract of Mentha Spicata L (Lamiaceae). Trop J Pharm Res. 2014;13(1):101-7.

16. Lastra G, Syed S, Kurukulasuriya LR, Manrique C, Sowers JR. Type 2 diabetes mellitus and hypertension: An update. Endocrinol Metab Clin North Am. 2014;43(1):103-22.

17. Boustany CM, Bharadwaj K, Daugherty A, Brown DR, Randall DC, Cassis LA Activation of the systemic and adipose renin-angiotensin system in rats with diet-induced obesity and hypertension. Am J Physiol - Regul Integr Comp Physiol. 2004;287(4 56-4):943-9.

18. Tardif J-C. Angiotensin-converting enzyme inhibitors and atherosclerotic plaque: a key role in the cardiovascular protection of patients with coronary artery disease. Eur Hear J Suppl. 2009 Aug 1;11(Suppl E):E9-16.

19. Voors AA, Veldhuisen DJ van, Gilst WH van. The Current Role of ACE-inhibitors for Secondary Prevention in Cardiovascular Disease; from Pathogenesis to Clinical Practice. Cardiovasc Drugs Ther. 2006;20(1):69-73.

20. Fadillah RU. Antidiabetic Effect of Morinda Citrifolia L. As A Treatment of Diabetes Mellitus. J Major. 2014;3(7):107-12

21. Lee SY, Park SL, Hwang JT, Yi SH, Nam Y Do, Lim S II. Antidiabetic effect of Morinda citrifolia (Noni) fermented by cheonggukjang in KK-A y diabetic mice. Evidence-based Complement Altern Med. 2012;1-8.

22. Muthia R, Suganda AG, Sukandar EY. Angiotensin-I Converting Enzyme ( ACE ) Inhibitory Activity Of Several Indonesian Medicinal Plants. Res J Pharm , Biol Chem Sci. 2017;8(1S):192-9.

23. Wigati D, Anwar K, Sudarsono, Nugroho AE. Hypotensive Activity of Ethanolic Extracts of Morinda citrifolia L. Leaves and Fruit in Dexamethasone-Induced Hypertensive Rat. J Evidence-Based Complement Altern Med. 2017;22(1):10713.

24. Bharati D, Rawat S, Sharma P. Evaluation of In vivo Efficacy of Aqueous Leaf Extract of Phyllanthus niruri in Diabetic Hypertensive Rats. Ann Clin Exp Hypertens. 2015;3(1031):1-7.

25. Stowe CB. The effects of pomegranate juice consumption on blood pressure and cardiovascular health. Complement Ther Clin Pract. 2011;17(2):113-5.

26. Intharachatorn T, Srisawat R. Antihypertensive Effects of Centella asiatica Extract. Int Proc Chem Biol Environ Eng. 2012;32(1):12-6.

27. Maneesai P, Bunbupha S, Kukongviriyapan U, Prachaney P, Tangsucharit P. Asiatic acid attenuates renin-angiotensin system activation and improves vascular function in high-carbohydrate, high-fat diet fed rats. BMC Complement Altern Med. 2016;1-11.

28. Ashraf K, Sultan S, Shah SAA. Phychemistry, Phytochemical, Pharmacological and Molecular Study of Zingiber officinale Roscoe: a Review. Int J Pharm Pharm Sci. 2017;9(10):8.

29. Kumar R, M, Kumar A, Kumar A. Pharmacological Activity of Zingiber officinale Int J Pharm Chem Sci Issn. 2012;1(3):1422-7 $\square \square \square$

30. Akhani SP, Vishwakarma SL, Goyal RK. Anti-diabetic activity of Zingiber officinale in streptozotocin-induced type I diabetic rats . J Pharm Pharmacol. 2004;56(1):101-5.

31. Ellya Roa Delima YMS. The effect of Cogongrass (Imperata cylindrica (L.) P. Beauv) in lowering blood pressure. https://repository.maranatha edu/12848/10/1110220_Journal.pdf.

32. Suraya A, Bariah S, Fattepur S, H H. Antidiabetic activity of ethanolic extract of Imperata cylindrical (lalang) leaves in alloxan induced diabetic rats. Arch Pharm Pract. 2012;3(1):46 
33. Nageswara Rao G, Ravi G, Sharath Kumar Goud S. Isolation and identification of anti oxidizing agents from Alyxia reinwardtii. J Pharm Sci Res. 2012;4(6):185960.

34. Eff ARY, Rahayu ST, Mahayasih PG, Januarko MU. Standardization of Indonesian traditional antihypertensive medicines (JAMU) through the ACE inhibitor mechanism. Pharmacogn J. 2020; 12 (3): 422-9.
35. Rajabi S, Ramazani A, Hamidi M, Naji T. Artemia salina as a model organism in toxicity assessment of nanoparticles. J Pharm Sci. 2015;23(1):1-6.

36. OS A, KM O, AO O. Assessment of Cytotoxic Activity of Calotropis Procera's Extracts Using Artemia Salina Assay. Biomed J Sci Tech Res. 2019;18(5):139536.

\section{GRAPHICAL ABSTRACT}

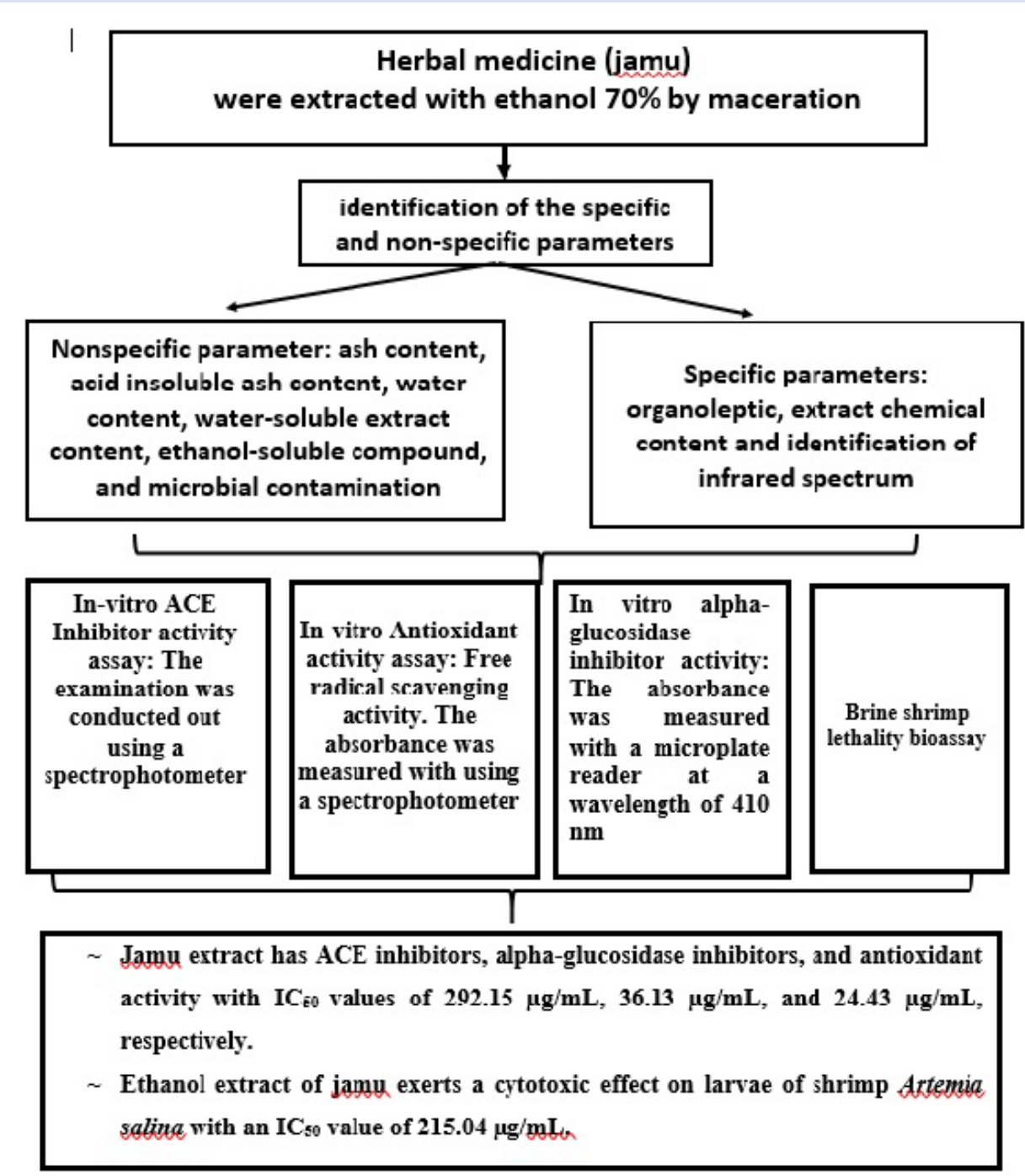

\section{ABOUT AUTHORS}

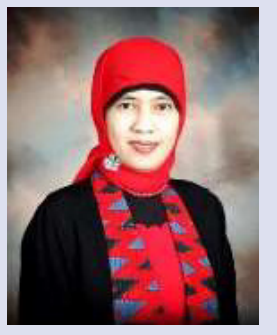

Aprilia Rina Yanti Eff was born in Tanjung Karang, Indonesia, in 1968. She received a bachelor's degree in Pharmacy from Padjadjaran University, Bandung, Indonesia, in 1992, and the M.Biomedic and Ph.D. degrees in Medical and Pharmacy Faculty, from the Universitas Indonesia, Jakarta, in 2001 and 2010, respectively. In 2001, she joined the Department of Pharmacy, UTA 45 Jakarta University as a Lecturer. Since 2015, She has been with the Department of Pharmacy, Esa Unggul University, where she has been an Assistant Professor, became an Associate Professor in 2010. Her current research interests include herbal medicine, Pharmacology, and clinical pharmacy. 


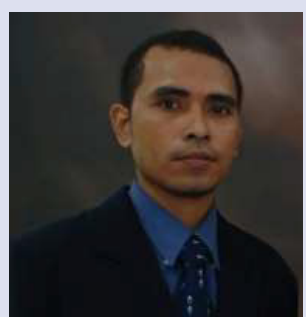

Hermanus Ehe Hurit, was born in Lewotala, Indonesia, in 1975. He received a bachelor's degree in Pharmacy from Universitas Katolik Widya Mandala, Surabaya, Indonesia, in 2001, he finished the Magister Pharmacy from the Universitas Pancasila Jakarta, in 2015. In 2018, hee joined the Department of Pharmacy, Esa Unggul University, as a Lecturer. His current research interests include pharmacology, herbal medidcine and clinical pharmacy.

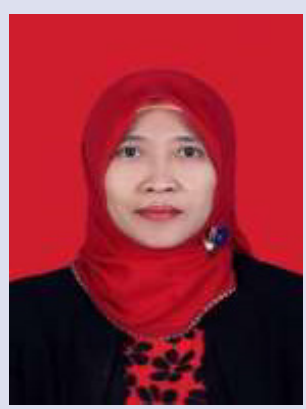

Sri Teguh Rahayu, was born in Jakarta, Indonesia, in 1972. She received a bachelor's degree in Pharmacy from Universitas 17 Agustus 1945, Jakarta, Indonesia, in 2006, she finished the Magister Pharmacy and Ph.D. degrees Pharmacy Faculty, from the Universitas Indonesia, Jakarta, in 2011 and 2018, respectively. In 2006, she joined the Department of Pharmacy, Universitas 17 Agustus 1945, Jakarta University as a Lecturer. Since 2015, he has been with the Department of Pharmacy, Esa Unggul University, where he has been an Assistant Professor in 2018. Her current research interests include pharmaceutical analysis, bioanalysis and herbal medicine.

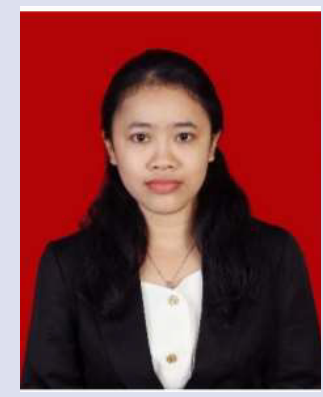

Putu Gita Maya W. Mahayasih, finished her magister program in pharmacy, at faculty of Pharmacy, Universitas Indonesia. She focused her research on natural product field. Currently, she is a lecture at Pharmacy department, faculty of health and sciences, Universitas Esa Unggul.

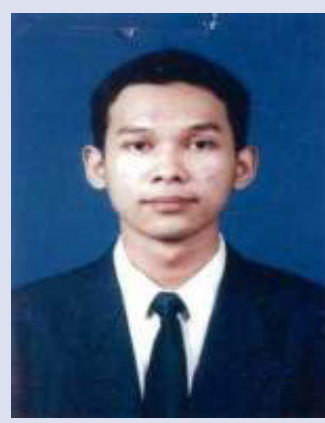

Moehammad Unggul Januarko, finished her magister program in Management, at faculty of Economic and Bussiness, Universitas Gajah Mada. She focused her research on management field. Currently, she is a lecture at Management department, faculty Economic and Bussiness, Universitas Esa Unggul.

Cite this article: Eff ARY, Hurit HE, Rahayu ST, Januarko MU, Maya WMPG. Antihypertensive, Antidiabetic, Antioxidant and Cytotoxic Activities of Indonesian Traditional Medicine. Pharmacogn J. 2020;12(6)Suppl:1623-9. 